\title{
Comparison of peptidase, glycosidase and esterase activities of oral and non-oral Treponema species
}

\author{
F. H. M. MIKX \\ Department of Periodontology and Preventive Dentistry, University of Nijmegen, PO Box 9101, \\ NL-6500 HB Nijmegen, The Netherlands
}

(Received 26 June 1990; revised 21 September 1990; accepted 1 October 1990)

\begin{abstract}
The enzyme profiles of 20 oral and non-oral Treponema strains were investigated using an API ZYM Complete Research kit. The test included 10 2-naphthyl derivatives of fatty acids, 20 -nitrophenol derivatives of carbohydrates and 60 2-naphthylamide derivatives of amino acids and peptides. The oral Treponema species investigated were $T$. denticola, $T$. vincentii and $T$. pectinovorum. The non-oral species examined were $T$. phagedenis, T. hyodysenteriae and intestinal spirochaetes of human and chicken origin. Esterase activities on $C_{5}$ to $C_{10}$ fatty acids were common among different Treponema species. Glycosidase activities were infrequently observed in $T$. vincentii, $T$. pectinovorum and $T$. phagedenis Reiter strain. Arabinosidase, lactosidase and xylosidase activity was observed in the $T$. hyodysenteriae strains but $\alpha$-L-fucosidase activity was found only in $T$. denticola and $T$. phagedenis. More exo- and endo-peptidase activities were found in $T$. denticola than in other species. The enteropathogenic $T$. hyodysenteriae isolates had a very low proteolytic profile. Dipeptidyl prolyl amidase activity was observed in all species except in the $T$. phagedenis Reiter strain and the avian intestinal spirochaetes. The enzyme profiles did not discriminate between oral and non-oral Treponema species.
\end{abstract}

\section{Introduction}

Spirochaetes are helical-shaped Gram-negative organisms which are prominent in subgingival plaque of inflamed periodontal tissue and in the microflora associated with the mucosa of the intestinal tract of man and animals with severe forms of diarrhoea (Harris et al., 1976; Listgarten \& Hellden, 1978; Sanna et al., 1982). Oral spirochaetes have been observed in gingival lesions in and between gingival epithelial cells (Listgarten, 1965; Mikx et al., 1990). Similar lesions have been described for $T$. hyodysenteriae in swine and chicken intestinal mucosa (Kennedy et al., 1973; Davelaar et al., 1986). The pathogenicity of $T$. hyodysenteriae is generally accepted. The pathogenicity of oral spirochaetes is still under discussion. Several oral treponemas can attach to epithelial cells and suppress cell proliferation, and have proteolytic enzymes which are considered of pathogenic importance (Olson 1984; Reijntjens et al., 1986; Uitto et al., 1986).

In order to compare the enzymic profiles of distinct pathogenic and other treponemas, 20 isolates were tested for the hydrolysis of a large number of synthetic substrates.

\section{Methods}

Oral Treponema strains. $T$. denticola ATCC 33520, Ny375 (a subgingival isolate; ter Steeg et al., 1988), B11 and B12 (isolated from periodontal boipsy; Mikx et al., 1989) and Ny576 (a subgingival isolate; this laboratory) were cultured anaerobically in BM broth (Gibbons \& MacDonald, 1960) with $25 \mathrm{mg}$ thiamin pyrophosphate $\mathrm{l}^{-1}$. $T$. vincentii ATCC 35580, LAl (a subgingival isolate; obtained from $R$. Taichman, Philadelphia, USA), CH3 (oral isolate; obtained from E. Chan, Montreal, Canada), Ny535 (isolated from gingival biopsy; this laboratory) and $T$. pectinovorum ATCC 337768 were cultured anaerobically in TYGVS broth (Laughton et al., 1981) with $0.8 \mathrm{~g} \mathrm{t}^{-1}$ galacturonic acid.

Non-oral Treponema strains. $T$. phagedenis Reiter (human isolate; RIVM, Bilthoven, The Netherlands) was cultured in Todd Hewitt broth (Difco). T. hyodysenteriae ATCC 271664, ATCC 31212 and T50 and T47, isolated from swine intestine (obtained from R.P.A.M. Segers, Utrecht, The Netherlands), chicken intestine isolates 1380 and 4742 (obtained from H. F. Smit, Doorn, The Netherlands) and human intestine isolates HRM4, HRM6, HRM13 and HRM14 (obtained from G. Dettori, Rome, Italy) were cultured anaerobically in TSBS broth (Sanna et al., 1982).

Enzyme assays. Bacterial cultures, 4-5 d old, were harvested by centrifugation and resuspended in $10 \mathrm{ml} 0.05 \mathrm{M}$-HEPES buffer, pH 7.2, to give an $\mathrm{OD}_{550}$ of at least 1.5 . According to the instructions of the manufacturer, drops of the suspension were added to cupules of the API ZYM Complete Research kit and incubated aerobically for $4 \mathrm{~h}$ at 
Table 1. Glycosidase activities of different Treponema species and intestinal spirochaetes of human and avian origin The explanation of scores is given in Methods. The number of strains tested is given in parentheses.

\begin{tabular}{|c|c|c|c|c|c|c|c|}
\hline \multirow[b]{2}{*}{$p$-Nitrophenol derivative } & \multirow[b]{2}{*}{$\begin{array}{l}\text { T. denticola } \\
\text { (4) }\end{array}$} & \multirow[b]{2}{*}{$\begin{array}{l}T \text {. vincentii } \\
\text { (4) }\end{array}$} & \multirow[b]{2}{*}{$\begin{array}{c}T . \text { pectinovorum } \\
\text { (1) }\end{array}$} & \multirow[b]{2}{*}{$\begin{array}{l}T \text {. phagedenis } \\
\text { (1) }\end{array}$} & \multirow[b]{2}{*}{$\begin{array}{c}\text { T. hyodysenteriae } \\
\text { (4) }\end{array}$} & \multicolumn{2}{|c|}{ Intestinal spirochaetes } \\
\hline & & & & & & $\underset{\text { (4) }}{\text { Human }}$ & $\begin{array}{l}\text { Avian } \\
\text { (2) }\end{array}$ \\
\hline$\alpha$-D-Galactose & 3 & 0 & 0 & 0 & 0 & 1 & 1 \\
\hline$\beta$-D-Galactose & 1 & $0^{*}$ & 0 & 0 & 3 & 2 & 1 \\
\hline$\alpha$-L-Arabinose & 0 & 0 & 0 & 0 & 1 & 0 & 0 \\
\hline$\alpha-D-G l u c o s e$ & 3 & 0 & 0 & 0 & 0 & 0 & 0 \\
\hline$\beta$-D-Glucose & 3 & 0 & 0 & 0 & 1 & $0 \dagger$ & 1 \\
\hline$\beta$-Maltose & 0 & 0 & 0 & 0 & 0 & $0+$ & 0 \\
\hline$N$-Acetyl- $\beta$-D-glucosamine & 1 & 2 & 2 & 1 & 1 & 1 & 1 \\
\hline$\alpha$-L-Fucose & 1 & 0 & 0 & 2 & 0 & 0 & 0 \\
\hline$\beta$-D-Fucose & 3 & $0^{*}$ & 0 & 0 & 2 & 2 & 1 \\
\hline$\beta$-D-Lactose & 0 & 0 & 0 & 0 & 1 & $0 \dagger$ & 0 \\
\hline$\beta$-D-Xylose & 0 & 0 & 0 & 0 & 1 & 0 & 0 \\
\hline
\end{tabular}

* Strain LAl score $2 . \quad$ † Strain HRM6 score 2.

Table 2. Esterase activities of different Treponema species and intestinal spirochaetes of human and avian origin

The explanation of scores is given in Methods. The number of strains tested is given in parentheses.

\begin{tabular}{|c|c|c|c|c|c|c|c|}
\hline \multirow[b]{2}{*}{ 2-Naphthyl derivative } & \multirow[b]{2}{*}{$\begin{array}{c}\text { T. denticola } \\
\text { (4) }\end{array}$} & \multirow[b]{2}{*}{$\begin{array}{c}T . \text { vincentii } \\
\text { (4) }\end{array}$} & \multirow[b]{2}{*}{$\begin{array}{c}T \cdot \text { pectinovorum } \\
\text { (1) }\end{array}$} & \multirow[b]{2}{*}{$\begin{array}{c}T \text {. phagedenis } \\
\text { (1) }\end{array}$} & \multirow[b]{2}{*}{$\begin{array}{c}\text { T. hyodysenteriae } \\
\text { (4) }\end{array}$} & \multicolumn{2}{|c|}{ Intestinal spirochaetes } \\
\hline & & & & & & $\begin{array}{l}\text { Human } \\
\text { (4) }\end{array}$ & $\begin{array}{l}\text { Avian } \\
\text { (2) }\end{array}$ \\
\hline Butyrate $C_{4}$ & 1 & 0 & 1 & 0 & 1 & 1 & 0 \\
\hline Valerate $C_{5}$ & 1 & 1 & 1 & 1 & 1 & 1 & 1 \\
\hline Caproate $\mathrm{C}_{6}$ & 3 & 2 & 2 & 2 & 3 & 3 & 2 \\
\hline Caprylate $\mathrm{C}_{8}$ & 3 & 2 & 2 & 2 & 3 & 3 & 2 \\
\hline Nonanoate $\mathrm{C}_{9}$ & 1 & 2 & 1 & 3 & 2 & 2 & 1 \\
\hline Caprate $\mathrm{C}_{10}$ & 2 & 0 & 1 & 0 & 1 & 2 & 0 \\
\hline Laurate $C_{12}$ & 1 & 0 & 1 & 1 & 1 & 0 & 0 \\
\hline Myristate $C_{14}$ & 1 & 0 & 0 & 0 & 0 & 0 & 0 \\
\hline Palmitate $\mathrm{C}_{16}$ & 1 & 0 & 0 & 0 & 0 & 0 & 0 \\
\hline Stearate $C_{18}$ & 1 & 2 & 1 & 0 & 1 & 1 & 0 \\
\hline
\end{tabular}

$37^{\circ} \mathrm{C}$. The API ZYM Complete Research kit allows the simultaneous study of 90 different enzymes: 10 esterases using 2-naphthyl derivatives of fatty acids, 20 glycosidases using $p$-nitrophenol (PNP) derivatives of carbohydrates and 60 peptidases using 2-naphthylamide derivatives of amino acids and peptides (API bio Merieux, Den Bosch, The Netherlands). Hydrolysis of the PNP derivatives gave a yellow colour (liberated PNP). Release of naphthylamide was estimated with the Fast blue reagents ZYM A and ZYM B. The reactions were read by the use of the API ZYM colour chart. According to the instructions of the manufacturer the scores 1 to 5 are related to 5 to $40 \mathrm{nmol}$ substrate hydrolysed. The median scores are presented in the Tables.

\section{Results}

The glycosidase activities of the different strains are presented in Table 1. T. denticola showed a larger number and higher levels of activities than the other oral strains. Only for $N$-acetyl- $\beta$-D-glucosaminidase was the activity higher in $T$. vincentii. The $\alpha$-L-fucosidase activity in $T$. denticola and $T$. phagedenis Reiter strain was particularly noteworthy. The swine $T$. hyodysenteriae strains showed some arabinosidase, lactosidase and xylosidase activity. Atypical results for $T$. vincentii $\beta$-Dgalactosidase and $\beta$-D-fucosidase activities were (score 2) found with one strain, LA1. This strain also gave different scores in the arylamidase tests (Tables 3 and 4). An atypical result was also found among the human intestinal spirochaetes with strain HRM6 (score 2).

The esterase activities are shown in Table 2. The strongest reactions were found using the derivatives of the $\mathrm{C}_{6}$ to $\mathrm{C}_{10}$ fatty acids.

The results of the peptidase activities are grouped according to the number of peptide bonds and the carboxy-terminal amino acid. Amino arylamidase activities were found in $T$. denticola but less so in other species 
Table 3. Amino arylamidase activities of different Treponema species and intestinal spirochaetes of human and avian origin The explanation of scores is given in Methods. The number of strains tested is given in parentheses.

\begin{tabular}{|c|c|c|c|c|c|c|c|}
\hline \multirow[b]{2}{*}{$\begin{array}{l}\text { 2-Naphthylamide } \\
\text { derivative }\end{array}$} & \multirow[b]{2}{*}{$\begin{array}{l}\text { T. denticola } \\
\text { (4) }\end{array}$} & \multirow[b]{2}{*}{$\begin{array}{l}\text { T. vincentii } \\
\text { (4) }\end{array}$} & \multirow[b]{2}{*}{$\begin{array}{l}\text { T. pectinovorum } \\
\text { (1) }\end{array}$} & \multirow[b]{2}{*}{$\begin{array}{l}\text { T. phagedenis } \\
\text { (1) }\end{array}$} & \multirow[b]{2}{*}{$\begin{array}{c}T . \text { hyodysenteriae } \\
\text { (4) }\end{array}$} & \multicolumn{2}{|c|}{ Intestinal spirochaetes } \\
\hline & & & & & & $\underset{(4)}{\text { Human }}$ & $\begin{array}{c}\text { Avian } \\
\text { (2) }\end{array}$ \\
\hline L-Ala & 1 & 0 & 0 & 0 & 0 & 2 & 0 \\
\hline L-Gly & 0 & 0 & 0 & 0 & 0 & 0 & 0 \\
\hline L-Pro & 3 & 0 & 0 & 0 & 0 & 0 & 0 \\
\hline L-hPro & 1 & $\mathbf{0}$ & 0 & 0 & 0 & 0 & 0 \\
\hline L-Ser & 1 & 0 & 0 & 0 & 0 & 0 & 0 \\
\hline L-Thr & 1 & 0 & 0 & 0 & 0 & 0 & 0 \\
\hline L-Phe & 1 & 0 & 0 & 0 & 0 & 0 & 0 \\
\hline L-Tyr & 1 & 0 & 0 & 0 & 0 & 0 & 0 \\
\hline L-Trp & 1 & 0 & 0 & 0 & 0 & 0 & 0 \\
\hline L-Arg & 2 & $0^{*}$ & 0 & 2 & 0 & 2 & 0 \\
\hline L-Lys & 1 & $0^{*}$ & $\mathbf{0}$ & 2 & 0 & 1 & 0 \\
\hline $\mathrm{L}-\mathrm{His}$ & 1 & $0^{*}$ & 0 & 2 & 0 & 0 & 0 \\
\hline $\mathrm{L}-\mathrm{G} \ln$ & 2 & 1 & 0 & 1 & 0 & 0 & 0 \\
\hline L-Asp & 1 & 0 & 0 & 0 & 0 & 0 & 0 \\
\hline L-Glu & 1 & 0 & 0 & 0 & 0 & 0 & 0 \\
\hline DL-Met & 1 & 0 & 0 & 1 & 1 & 2 & 0 \\
\hline L-Pyr & 3 & 0 & 0 & 2 & 0 & 0 & 0 \\
\hline
\end{tabular}

* Strain LAl score 3.

Table 4. Dipeptidyl arylamidase activities of different Treponema species and intestinal spirochaetes of human and avian origin The explanation of scores is given in Methods. The number of strains tested is given in parentheses.

\begin{tabular}{|c|c|c|c|c|c|c|c|}
\hline \multirow[b]{2}{*}{$\begin{array}{l}\text { 2-Naphthylamide } \\
\text { derivative }\end{array}$} & \multirow[b]{2}{*}{$\begin{array}{l}\text { T. denticola } \\
\text { (4) }\end{array}$} & \multirow[b]{2}{*}{$\begin{array}{l}\text { T. vincentii } \\
\text { (4) }\end{array}$} & \multirow[b]{2}{*}{$\begin{array}{l}\text { T. pectinovorum } \\
\text { (1) }\end{array}$} & \multirow[b]{2}{*}{$\begin{array}{l}\text { T. phagedenis } \\
\text { (1) }\end{array}$} & \multirow[b]{2}{*}{$\begin{array}{c}\text { T. hyodysenteriae } \\
\text { (4) }\end{array}$} & \multicolumn{2}{|c|}{ Intestinal spirochaetes } \\
\hline & & & & & & $\underset{(4)}{\text { Human }}$ & $\begin{array}{c}\text { Avian } \\
\text { (2) }\end{array}$ \\
\hline L-Asp-L-Ala & 1 & 1 & 0 & 1 & 0 & 0 & 0 \\
\hline Gly-L-Ala & 1 & 0 & 0 & 0 & 0 & 0 & 0 \\
\hline L-Leu-L-Ala & 1 & 0 & 0 & 0 & 0 & 0 & 0 \\
\hline L-Lys-L-Ala & 1 & 0 & 0 & 0 & 0 & 0 & 0 \\
\hline Gly-Gly & 1 & 0 & 0 & 0 & 0 & 0 & 0 \\
\hline L-Leu-Gly & 1 & 0 & 0 & 0 & 0 & $\mathbf{0}$ & 0 \\
\hline Gly-L-Pro & 2 & 1 & 1 & 0 & 1 & $0 \dagger$ & 0 \\
\hline L-Phe-L-Pro & 3 & 1 & 1 & 0 & 1 & 1 & 0 \\
\hline L-His-L-Ser & 1 & 0 & 0 & 0 & 0 & 0 & 0 \\
\hline Gly-L-Phe & 2 & 0 & 0 & 0 & 0 & 0 & 0 \\
\hline L-His-L-Phe & 1 & 0 & 0 & 0 & 0 & 0 & 0 \\
\hline L-Ser-L-Tyr & 1 & 0 & 0 & 1 & 0 & 0 & 0 \\
\hline Gly-L-Trp & 1 & 0 & 0 & 1 & 0 & 0 & 0 \\
\hline L-Ala-L-Arg & 2 & $0^{*}$ & 0 & 0 & 0 & 0 & 0 \\
\hline L-Asp-L-Arg & 1 & $0^{*}$ & 0 & 1 & 0 & $0 \dagger$ & 0 \\
\hline Gly-L-Arg & 2 & $0^{*}$ & 0 & 1 & 0 & 0 & 0 \\
\hline L-Phe-L-Arg & 2 & $0^{*}$ & 0 & 0 & 0 & 0 & 0 \\
\hline L-Arg-L-Arg & 2 & $0^{*}$ & 0 & 0 & 0 & 0 & 0 \\
\hline L-Pro-L-Arg & 2 & $0^{*}$ & 0 & 0 & 0 & 0 & 0 \\
\hline L-Lys-L-Lys & 2 & $0^{*}$ & 0 & 0 & 0 & 0 & 0 \\
\hline L-Gin-L-His & 0 & $0^{*}$ & 0 & 1 & 0 & 0 & 0 \\
\hline L-Gln-L-Glu & 0 & 0 & 0 & 1 & 0 & 0 & 0 \\
\hline L-Ser-L-Met & 1 & 0 & 0 & 2 & 0 & 0 & 0 \\
\hline
\end{tabular}


Table 5. Oligopeptidyl arylamidase activities of different Treponema species and intestinal spirochaetes of human and avian origin

The explanation of scores is given in Methods. The number of strains tested is given in parentheses.

\begin{tabular}{|c|c|c|c|c|c|c|c|}
\hline \multirow[b]{2}{*}{$\begin{array}{l}\text { 2-Naphthylamide } \\
\text { derivative* }\end{array}$} & \multirow[b]{2}{*}{$\begin{array}{l}\text { T. denticola } \\
\text { (4) }\end{array}$} & \multirow[b]{2}{*}{$\begin{array}{l}\text { T. vincentii } \\
\text { (4) }\end{array}$} & \multirow[b]{2}{*}{ T. pectinovorum } & \multirow[b]{2}{*}{$\begin{array}{l}\text { T. phagedenis } \\
\text { (1) }\end{array}$} & \multirow[b]{2}{*}{$\begin{array}{c}\text { T. hyodysenteriae } \\
\text { (4) }\end{array}$} & \multicolumn{2}{|c|}{ Intestinal spirochaetes } \\
\hline & & & & & & $\underset{(4)}{\text { Human }}$ & $\begin{array}{l}\text { Avian } \\
(2)\end{array}$ \\
\hline $\begin{array}{l}\text { L-Ala-L-Phe-L-Pro-L-Ala } \\
\text { L-Phe-L-Pro-L-Ala }\end{array}$ & $\begin{array}{l}2 \\
2\end{array}$ & $\begin{array}{l}0 \\
0\end{array}$ & $\begin{array}{l}0 \\
0\end{array}$ & $\begin{array}{l}0 \\
1\end{array}$ & $\begin{array}{l}\mathbf{0} \\
\mathbf{0}\end{array}$ & $\begin{array}{l}0 \\
0\end{array}$ & $\begin{array}{l}0 \\
0\end{array}$ \\
\hline L-Ala-L-Phe-L-Pro & 3 & 0 & 0 & 0 & 0 & 1 & 0 \\
\hline $\begin{array}{l}\text { L-Leu-L-Leu-L-Val-L-Tyr-L-Ser } \\
\text { L-Val-L-Tyr-L-Ser }\end{array}$ & $\begin{array}{l}1 \\
1\end{array}$ & $\begin{array}{l}0 \\
0\end{array}$ & $\begin{array}{l}0 \\
0\end{array}$ & $\begin{array}{l}0 \\
1\end{array}$ & $\begin{array}{l}0 \\
0\end{array}$ & $\begin{array}{l}1 \\
0\end{array}$ & $\begin{array}{l}0 \\
0\end{array}$ \\
\hline $\begin{array}{l}N \text {-CBZ-Gly-Gly-L-Arg } \\
N \text {-CBZ-Gly-Gly-L-Arg } \\
N \text {-Acetyl-Gly-L-Lys } \\
\text { L-His-L-Leu-L-His }\end{array}$ & $\begin{array}{l}3 \\
3 \\
2 \\
1\end{array}$ & $\begin{array}{l}0 \\
0 \\
0 \\
0\end{array}$ & $\begin{array}{l}0 \\
0 \\
0 \\
0\end{array}$ & $\begin{array}{l}0 \\
0 \\
0 \\
0\end{array}$ & $\begin{array}{l}0 \\
0 \\
0 \\
0\end{array}$ & $\begin{array}{l}0 \\
0 \\
0 \\
0\end{array}$ & $\begin{array}{l}0 \\
0 \\
0 \\
0\end{array}$ \\
\hline
\end{tabular}

* CBZ, carbobenzoxy.

Table 6. Amino-, di- and oligo-peptidase activities of different Treponema species and intestinal spirochaetes of human and avian origin

The number of strains tested is given in Tables 1-5. Activities of aminopeptidase (A), dipeptidase (D) or oligopeptidase (O) were either present $(+)$ or absent $(-)$. v, Variable, with strain LAl positive and the other strains negative. NT, not tested.

\begin{tabular}{|c|c|c|c|c|c|c|c|c|c|c|c|c|c|c|c|c|c|c|c|c|c|}
\hline \multirow{3}{*}{$\begin{array}{l}\text { C-terminal } \\
\text { amino acid in } \\
\text { 2-naphthylamide } \\
\text { derivative }\end{array}$} & \multirow{2}{*}{\multicolumn{3}{|c|}{$T$. denticola }} & \multirow{2}{*}{\multicolumn{3}{|c|}{$T$. vincentii }} & \multirow{2}{*}{\multicolumn{3}{|c|}{$T \cdot$ pectinovorum }} & \multirow{2}{*}{\multicolumn{3}{|c|}{$T$. phagedenis }} & \multirow{2}{*}{\multicolumn{3}{|c|}{$T$. hyodysenteriae }} & \multicolumn{6}{|c|}{ Intestinal spirochaetes } \\
\hline & & & & & & & & & & & & & & & & \multicolumn{3}{|c|}{ Human } & \multicolumn{3}{|c|}{ Avian } \\
\hline & A & D & $\mathrm{O}$ & $\mathbf{A}$ & $\mathbf{D}$ & $\mathbf{O}$ & A & $\mathrm{D}$ & $\mathrm{O}$ & $\mathbf{A}$ & D & $\mathbf{O}$ & $\mathbf{A}$ & $\mathrm{D}$ & $\mathbf{O}$ & A & $\mathbf{D}$ & $\mathbf{O}$ & A & $\mathrm{D}$ & $\mathrm{O}$ \\
\hline Alanine & + & + & + & - & - & - & - & - & - & - & - & + & - & - & - & + & - & - & - & - & - \\
\hline Proline & + & + & + & - & + & - & - & + & - & - & - & - & - & + & - & - & + & + & - & - & - \\
\hline Serine & + & + & + & - & - & - & - & - & - & - & - & + & - & - & - & - & - & + & - & - & - \\
\hline Tyrosine & + & + & NT & - & - & NT & - & - & - & - & + & NT & - & - & NT & - & - & NT & - & - & NT \\
\hline Arginine & + & + & + & $\mathrm{v}$ & $\mathbf{v}$ & - & - & - & - & + & + & - & - & - & - & + & - & - & - & - & - \\
\hline
\end{tabular}

(Table 3). Arginyl amidase activity was observed in $T$. denticola, $T$. phagedenis and in the human strains of $T$. hyodysenteriae. Pyrrolidonyl amidase activity (L-Pyr) was only found in $T$. denticola and $T$. phagedenis. Dipeptidyl arylamidase activities were mainly found in $T$. denticola (Table 4). Dipeptidyl prolyl activities were observed in $T$. hyodysenteriae and in all the oral and human intestinal isolates. $T$. denticola showed oligopeptidyl arylamidase activities for all the substrates tested (Table 5).

The amino-, di- and oligopeptidase activities are summarized in Table 6. The grouping of the activities towards 2-naphthylamide derivatives according to the carboxy-terminal amino acid showed a consistent pattern. The most frequently observed activities among the 20 Treponema strains investigated were prolyl and arginyl amidases. $T$. denticola showed the widest variety of activities, followed by $T$. phagedenis Reiter strain and the human intestinal strains.

\section{Discussion}

The enzymic profiles of different pathogenic and nonpathogenic strains of Treponema were compared in order to look for indications of common putative pathogenic activities. Care was taken to test and score the twenty isolates uniformly. However, the different species had to be grown in different media, which might have influenced the presence of inducible enzymes. There was, however, no indication of a medium effect when the results of the API ZYM Complete Research kit were compared with those of the API, ZYM or Rap ID-ANA systems using other culture media (Hunter \& Wood, 1979; Syed et al., 1988; Fukumoto et al., 1987).

Most glycosidase activities detected in $T$. denticola were also present in the intestinal spirochaetes. In addition, the $T$. hyodysenteriae isolates showed arabinosidase, lactosidase and xylosidase activities. These activities might be of nutritional value in the swine gut, or, as is 
possible for $\alpha$-L-fucosidase in $T$. denticola, in contact with salivary glycoproteins. The glycosidase profiles of $T$. vincentii, $T$. pectinovorum and $T$. phagedenis resemble those of the small spirochaetes investigated by Fiehn (1986) and indicate that these species probably depend on substrates as carbon and energy source which differ from those used by $T$. denticola and the intestinal spirochaetes.

Esterase activities were common among all the Treponema species investigated. Esterases play a role in nutrition and probably, in conjunction with phospholipase activities, in tissue destruction. Phospholipases have not, however, been found in the enteropathogenic $T$. hyodysenteriae isolates (Trevathan et al., 1982; Sibo et al., 1989).

In addition to the present extended comparative study, previous work on the enteropathogenic species $T$. hyodysenteriae has given no indication of a high proteolytic activity nor of a common peptidase activity among the swine, human and chicken intestinal strains. The human intestinal spirochaetes, the swine $T$. hyodysenteriae strains and also the oral Treponema species showed a dipeptidyl-prolyl amidase activity. This activity may indicate a requirement for proline peptides, as has been shown in other anaerobic bacteria (Wahren \& Holme, 1973).

The observed enzymic activities for the 60 different amino acid and peptide naphthylamide derivatives could be grouped according to the carboxy-terminal amino acid. Arylamidases of $T$. denticola specific for alanine, proline, tyrosine or basic reidues have also been found in other oral bacteria. Fukasawa et al. (1982) suggested that these enzymes play a role in the degradation of certain salivary proteins and in the provision of nitrogenous growth substrates. Others have indicated that the proteases of Bacteroides gingivalis (recently named Porphyromonas gingivalis) and oral spirochaetes mediate tissue destruction and perturbation of the host defences during the pathogenic process of periodontal disease (Ohta et al., 1986; Mikx \& de Jong, 1987; Carlsson et al., 1986). Initiation of periodontal lesions by oral spirochaetes has also been postulated, although in periodontal disease a mixed microbial infection is involved (Maltha et al., 1985). Recently Grenier et al. (1990) demonstrated a chymotrypsin-like protease of $T$. denticola on the outside of the cell and suggested a function of this enzyme in invasion and destruction of the basement membrane. However, a model infection system for oral spirochaetes is lacking, and the spirochaetes found in and between junctional epithelial cells are probably not T. denticola (Mikx et al., 1990). ter Steeg et al. (1988) showed that $T$. denticola can be enriched on human serum and can take part in consortia associated with periodontal destruction. The proteolytic activities of $T$. denticola might be of importance for its participation and the concerted action of the consortium in periodontal pockets and surrounding tissues (ter Steeg \& van der Hoeven, 1990).

In conclusion, the enzyme profiles of the 20 oral and non-oral Treponema strains showed some common esterase and $N$-acetyl- $\beta$-D-glucosaminidase activities. The profiles did not discriminate between oral and nonoral treponemas. With the exception of $T$. denticola, pathogenic and non-pathogenic Treponema species showed a low proteolytic profile. Dipeptidyl prolyl amidase activity was observed in all species except $T$. phagedenis strain Reiter and the avian intestinal spirochaetes.

I would like to thank Giuseppe Dettori of the Medical Faculty of the University del Sacro Cuore in Rome, Ruud Segers and Harm Smit of the Veterinary Faculty of the University of Utrecht, and Sjoerd Rijpkema of RIVM Bilthoven, The Netherlands, for the provision of strains and for their useful comments on the manuscript.

\section{References}

Carlsson, J., Nilsson, T. \& LundQuist, G. (1986). Effect of proteinases from black pigmented Bacteroides on human plasma proteins. In The Borderland between Caries and Periodontal Disease III, pp. 155-163. Edited by T. Lehner \& G. Cimasoni. Geneva: Editions Médicines et Hygiène.

Davelaar, F. G., Smit, H. F., Houvin Hougen, K., Dwars, R. M. \& VAN DEN VALK, P. C. (1986). Infectious typhlitis in chickens caused by spirochetes. Avian Pathology 15, 247-258.

FiEHN, N. E. (1986). Enzyme profiles from eight small-sized oral spirochetes. Scandinavian Journal of Dental Research 94, 132-140.

Fukasawa, K., Hiraoka, B. Y., Fukasawa, K. M. \& Harada, M. (1982). Arylamidase activities specific for proline, tyrosine and basic amino acid residues in some oral bacteria. Journal of Dental Research 61, 818-820.

Fukumoto, Y., OKuda, K., Kato, T. \& Takazoe, I. (1987), Taxonomic study of spirochetes isolated from human periodontal lesions. Oral Microbiology and Immunology 2, 82-87.

Gibbons, R. J. \& MacDonald, J. B. (1960). Hemin and vitamin K compounds as required factors for the cultivation of certain strains of Bacteroides melaninogenicus. Journal of Bacteriology 80, 164-170.

Grenier, D., UitTo, M. J. \& McBride, B. C. (1990). Cellular location of a Treponema denticola chymotrypsin like protease and importance of the protease in migration through the basement membrane. Infection and Immunity 58, 347-351.

HaRris, D. L., GloCK, R. D. \& Kinyon, J. M. (1976). Intestinal treponematoses. In The Biology of Parasitic Spirochetes, pp. 277-294. Edited by R. C. Johnson. New York: Academic Press.

HUNTER, D. \& WOOD, T. (1979). An evaluation of the API-ZYM system as a means of classifying spirochaetes associated with swine dysentery. Veterinary Record 104, 383-384.

Kennedy, G. A., Strafuss, A. C. \& Schoenweis, D. A. (1973) Scanning electronic microscopic observations on swine dysentery. Journal of American Veterinary Association 163, 53-55.

LAughton, B. E., Syed, S. A. \& LoESCHE, W. J. (1981). API-ZYM system for identification of Bacteroides spp., Capnocytophaga spp. and spirochetes of oral origin. Journal of Clinical Microbiology 15 97-102.

LISTGARTEN, M. A. (1965). Electron microscopic observations on the bacterial flora of acute nectrotizing ulcerative gingivitis. Journal of Periodontology 136, 328-339. 
Listgarten, M. A. \& Hellden, L. (1978). Relative distribution of bacteria at clinically healthy and periodontally diseased sites in humans. Journal of Clinical Periodontology 5, 115-132.

Maltha, J. C., MikX, F. H. M. \& KuYPers, F. J. (1985). Necrotizing ulcerative gingivitis in beagle dogs. III. Distribution of spirochetes in interdental gingival tissue. Journal of Periodontal Research 20, 522531.

MIKX, F. H. M. \& DE JoNG, M. H. (1987). Keratinolytic activity of cutaneous and oral bacteria. Infection and Immunity 55, 621-625.

Mikx, F. H. M., Maltha, J. C. \& Keulers, R. A. C. (1989). Are there differences between oral Treponema in dental plaque and gingival tissue? Journal of Dental Research 68, abstract 87

Mikx, F. H. M., Maltha, J. C. \& van Campen, G. J. (1990). Spirochetes in early lesion of necrotizing ulcerative gingivitis, experimentally induced in beagle dogs. Oral Microbiology and Immunology 5, 86-89.

Ohta, K. Makinen, K. K. \& Loesche, W. J. (1986). Purification and characterization of an enzyme produced by Treponema denticola capable of hydrolyzing synthetic trypsin substrates. Infection and Immunity 53, 213-220.

OLSON, I. (1984). Attachment of Treponema denticola to cultured human epithelial cells. Scandinavian Journal of Dental Research 92, 55-63.

ReIJNTJENS, F. M. J., Mikx, F. H. M., Wolters Lutgerhorst, J. M. L. \& MaLTHA, J. C. (1986). Adherence of oral treponemas and their effect on morphological damage and detachment of epithelial cells in vitro. Infection and Immunity 51, 642-647.
Sanna, A., Dettori, G., Grillo, R., Rossi, A. \& Chiarenza, D. (1982). Isolation and propagation of a strain of Treponema from the human digestive tract - preliminary report. L'Igiene Moderna 77, 287-297.

Sibo, R., Al-Joburi, W., GoRnitsky, M. \& Chan, E. C. S. (1989) Synthesis and secretion of phospholipase $\mathrm{C}$ by oral spirochetes. Journal of Clinical Microbiology 27, 568-570.

TER STEEg, P. F. \& VAN DER HoEven, J. S. (1990). Growth stimulation of Treponema denticola by periodontal microorganisms. Antonie van Leeuwenhoek 57, 63-70 (abstract).

ter Steeg, P. F., van der Hoeven, J. S., de Jong, M. H., van Munster, P. J. \& Jansen, M. J. H. (1988). Modelling the gingival pocket by enrichment of subgingival microflora in human serum in chemostats. Microbial Ecology in Health and Disease 1, 7384.

Syed, S. M., SalvadoR, S. L. \& Loesche, W. J. (1988). Enzyme profiles of oral spirochetes in Rap ID-ANA system. Journal of Clinical Microbiology 26, 2226-2228.

Trevathan, C. A., Smibert, R. M. \& George, H. A. (1982). Lipid catabolism of cultivated treponemas. Canadian Journal of Microbiology 28, 672-678.

UitTo, V. J., Chan, E. C. S. \& ChIN QueE, T. (1986). Initial characterization of neutral proteinases from oral spirochetes. Journal of Periodontal Research 21, 95-100.

W AHREN, A. \& Holme, T. (1973). Amino acid and peptide requirement of Fusiformis necrophorus. Journal of Bacteriology 116, 279-284, 